25. Лингвистическое источниковедение и история русского языка (2010-2011). - М.: Древлехранилище, 2011.

26. Котков С. И. Лингвистическое источниковедение и история русского языка. - М.: Наука, 1980.

27. Он же. Таможенные книги Камер-коллегии - источники по истории русского языка // Русское и славянское языкознание. К 70-летию Р.И. Аванесова. - М.: Наука, 1972.

28. Мордкович М.В. Типы лексических замен в Архангельской таможенной книге 1719 г. / автореф. дис. ... канд. филол. наук. - М., 2000.

29. Захарова Ю.Г. Сольвычегодские таможенные книги XVIII века как лингвистический источник / автореф. дис. ... канд. филол. наук. - Хабаровск, 2002.

30. Баракова О. В. Деловая письменность XVII века: концептосфера, субтекстовый состав: На материале таможенных книг Московского государства / Автореф. дисс. ... д-ра филол. наук. - 2004.

31. Малышева И.А. Памятники деловой письменности XVIII века как объект лингвистического источниковедения. - Хабаровск, 1997.

32. ТК 12 - Кеврольская таможенная книга 1712 г., № 611, 116 л. - Ф. 10, оп. 3 (Архангелогородская губернская канцелярия). Архив Санкт-Петербургского института истории PAH.
33. ТК 13 - Кеврольская таможенная книга 1713 г., № 719, 215 л. - Ф. 10, оп. 3 (Архангелогородская губернская канцелярия). Архив Санкт-Петербургского института истории РАН.

34. ТК 21 - Кеврольская таможенная книга 1721 г., № 32764 , 514 л. - Ф. 273, оп. 1, ч. 8 (Камер-коллегия). Российский государственный архив древних актов.

35. Коркина Т.Д. Языковые особенности формуляра кеврольских таможенных книг начала XVIII века (на материале кеврольской таможенной книги 1713 г.) // Региональные варианты национального языка: материалы всероссийской (с международным участием) научной конференции / науч. ред. А.П. Майоров. - Улан-Удэ: Изд-во Бурятского госуниверситета, 2013.

36. Словарь русского языка XI-XVII вв. - Вып. 25. - СПб.: Наука; Азбуковник, 2000.

37. Малышева И.А. 0 Словаре торговой лексики XVIII века // Актуальные вопросы исторической лексикографии и лексикологии. Материалы Всероссийской Академической школысеминара. - СПб.: Наука, 2005.

38. Палагина В.B. Томские таможенные книги как источник реконструкции лексики разговорной речи первой половины XVII века // Актуальные проблемы лексикологии и словообразования. Вып. 7. - Новосибирск, 1978.

39. Памятники южновеликорусского наречия: Таможенные книги / подгот. С.И. Котков, Н.С. Коткова. - М.: Наука, 1982.

УДК 821.352.30: 391

ББК $83.3(=602.2) ; 71.0$

\title{
И.А. КАЖАРОВА
}

\section{«КОСТЮМНЫЙ ОБЛИК» КАК СПОСОБ КОНКРЕТИЗАЦИИ ИДЕАЛА}

Рассматривается взаимодействие разнонаправленных ценностей через «костюмный облик» героя поэтического произведения. На материале кабардинской поэзии XX века показано, что наибольшей информативностью детали костюма обладают в произведениях, появившихся в период радикальных преобразований общества, однако лишь в контексте женского одеяния наблюдается сопоставление/противопоставление прошлого и современности.

Ключевые слова: идеализация, деталь костюма, «новый человек», система ценностей, нормативы, адыгская культура, художественное сознание, ментальные представления.

0 дна из стадий идеализации человека, которая в процессе осмысления поэтического произведения чаще всего оказывается оттесненной на периферию исследовательского интереса, - внешность. Если в прозаическом тексте описание облика, в частности одежды, способствует раскрытию характера героя и духа эпохи, то в тексте поэтическом посредством ритма, звука и об-

\footnotetext{
${ }^{1}$ Статья подготовлена в рамках Программы фундаментальных исследований Президиума РАН «Традиции и инновации в истории и культуре» по направлению 5. «Механизмы преемственности в развитии литературы». Проект «Специфика актуализации культурных идеалов в кабардинской поэзии XX века».
}

раза, создающего эмоциональный сгусток реальности, требуется сжатие описательных приемов. Поэтому из многообразия предметного мира в текст не попадает ничто второстепенное, - попадает лишь то, что значимо на взгляд автора. Да и само понятие «облик», отнесенное к герою поэзии, привычнее наблюдать в сочетании с определениями «духовный», «моральный», «нравственный» и т. п. Костюмный же аспект как элемент вещного мира, далекого от человеческой метафизики, автоматически причисляется к области наиболее заурядных средств создания этого облика. В этом отношении определяющее значение вложено в заглавие культурологического исследования И.А. Манкевич, где одним из ключевых объектов 
«повседневной культуры» и «литературной культуры» [1, с. 6] показаны костюмы героев русской классики - «Поэтика обыкновенного».

Российская поэзия XX века с точки зрения внешнего облика ее героев пока не изучена, между тем этапы ее истории, на которых устремленность к идеалу человека выразилась с особой экспрессией, интересны с точки зрения культурных смыслов, просматривающихся через их «костюмный антураж», и раскрывают свою многосложность в произведениях на национальных языках.

Показать значимость костюмных деталей (либо отсутствие таковых) в построении идеала человека в кабардинской поэзии прошедшего века, при этом уделить особое внимание раннесоветскому времени, императивной тенденцией которого выступила апология так называемого нового человека, - задача данного исследования.

Это был период, в котором понятные и привычные для адыгского этноса модели художественности оттеснялись нормативами новой, инородной культуры; за короткий промежуток времени надлежало отойти от привычной стилистики родной культуры и принять каноны новой реальности.

В дошедших до нас поэтических произведениях этого времени не наблюдается особых художественных открытий, поскольку в свете жесткой идеологической нормативности их и не могло быть. «0бщим местом» их критической оценки является то, что все задействованные в них средства подчиняются общей идее, однако подробное рассмотрение деталей, как нам представляется, делает очевидным то «неподчинение образа» идеологическим нормативам, которое иной раз даже помимо воли художника говорит многое о ценностном ядре идеала.

В упомянутом выше исследовании И.А. Манкевич есть ряд понятий, обособляющих предмет исследования данной статьи: «костюмные характеристики», «костюмные ремарки», «костюмный облик», «костюмные смыслы», «костюмные тексты» которые символизируют смену времен, конфликт идеологий, воспитания, образа жизни, социального опыта [1, с. 624].

Идейная подоплека культурных явлений раннесоветского этапа, отраженная в литературах, именуемых «новописьменными», кажется очевидной настолько, что порой загораживает многоплановость того времени. Не составляет в этом отношении исключения пролетарская поэзия классика кабардинской литературы Али Асхадовича Шогенцукова (1900-1941) и его современников - Мухамеда Абубекировича Афаунова (1907-1937) и Абдула

\footnotetext{
2 Адыги (черкесы) - самоназвание единого этноса, в советский период разделенного на адыгейцев, кабардинцев, черкесов. Являются автохтонным населением Северо-Западного Кавказа и Восточного Причерноморья (Адыгея, Кабардино-Балкария, Карачаево-Черкесия, Краснодарский край). Часть адыгов, вынужденно переселившаяся в Османскую империю во время и по окончании Кавказской войны (1817-1864), проживает сейчас в ряде стран зарубежья. Язык адыгов делится на нижне-адыгский (адыгейский) и верхне-адыгский (кабардино-черкесский). В исследованиях любого рода определение «адыгский» выступает как объединяющее по отношению к определениям «кабардинский», «черкесский», «адыгейский».
}

Каншаовича Пшенокова (1907-1937). Попытка рассмотреть их тексты с точки зрения «костюмных смыслов» уже в первом приближении позволяет предположить, что в произведениях, появившихся в период решительных социальных перемен, выбор идеала осуществлялся, в том числе, и через выбор костюмного облика.

Очевидно, что наиболее масштабно перемены, наметившиеся в привычном укладе кабардинцев с установлением советской власти, сказывались на судьбе женщины, которая ранее могла проявлять себя в общественной жизни лишь неформально, опосредованно [2; 3], поэтому становление идеала нового человека через ее образ вырастало в отдельную тему художественных поисков.

В свете радикальных перемен, которые влекли неизбежный поиск новых эталонов, была вполне органична героиня появившегося в 1931 году стихотворения А. Шогенцукова «Лина-трактористка». Чтобы понять, насколько сильна была степень ее «новизны», обратим внимание на одно обстоятельство. Кабардино-черкесское существительное, как известно, не знает категории рода, между тем черновые варианты произведений Шогенцукова, опубликованные в двухтомнике 1961 года, позволяют видеть, что внедряя слово другого языка в название своего произведения, поэт колеблется в выборе его рода: «Линэ трактористкэщ»/«Линэ трактористщ» - «Линатрактористка»/«Лина-тракторист». В этом колебании своеобразный поиск формы для выражения новых запросов, предъявляемых к женщине: «Мужчинам подобно, во имя житья / Чтобы трудились, вам дали свободу»³ [4, с. 296]. Как указывает в комментариях к сборнику исследователь творчества Шогенцукова А.Х. Хакуашев, впервые это слово фигурирует в сборнике «Артель» (1931) именно как «Лина-тракторист» [5, с. 526].

Сообразно роли, востребованной в предлагаемых обстоятельствах, речь в произведении шла о девушке, оседлавшей «сурового железного коня». В плане эстетики этого образа новизна передавалась лишь через каноническую для новой действительности деталь одежды - развевающуюся на ветру красную косынку. Не видно ни лица героини, ни жестов, только результаты действий - чернеющая пашня и сметаемые на пути юной трактористки заросли. В четырех строфах из пяти, составивших стихотворение, героиня обозначена метафорически, через деталь одежды («красная косынка», «красная головка»), имя же собственное - Лина - присутствует только в заглавии произведения. Типизация образа, по сути, сведена здесь к отсутствию внешних черт. Есть только покоряемая действительность и яркий атрибут покорительницы. Но подобный образ и, главное, намеченный им этико-эстетический вектор в освещении идеала новой женщины, судя по произведениям тех лет, закрепляется в творчестве Шогенцукова ненадолго.

В 1935 году в кабардинскую поэзию входит ряд произведений, приуроченных к Первому съезду трудящейся

\footnotetext{
3 Здесь и далее подстрочные переводы художественных текстов сделаны мною. - И.К.
} 
женской молодежи Северо-кавказского края. При этом стоит отметить особую значимость этого события, вызвавшего оживленную реакцию молодой кабардинской интеллигенции. Характер съезда уже не ощутим с позиции сегодняшнего дня, но в свете адыгских ментальных представлений рассматриваемого периода он ознаменовал поистине кардинальное преобразование.

История областных и краевых съездов горских женщин, как известно, начинается с 1922 года, но, заметим, съезды эти по какой-то причине не акцентированы художественным сознанием. Сила же эмоционального воздействия Первого краевого съезда женской молодежи становится очевидной, если принять во внимание силу «фактора традиционной половозрастной субординации», на который указывает в своем исследовании историк М. Текуева. Этот фактор предполагал «не только почтение к старшим, но и то, что женщина в преклонном возрасте обладала значительно более значимым социальным статусом и имела больше возможностей в публичной самопрезентации, нежели в молодые годы. От молодежи требовалось понимание "своего места" и уважительное отношение к приоритетным позициям старших» [6]. Исходя из этого, замечает исследователь, для участия в общественных мероприятиях преимущественно делегировались представительницы старшего поколения. Значит, именно в 1935 году в политическую жизнь официально и полноправно входит молодая кабардинка. Героем произведений становится цІыхубзыщІэ («новая женщина»), - прямолинейность выражения, прочно вошедшего в поэтический язык эпохи, вполне отражает ее этические ожидания. Но если изучить детали с точки зрения вводимой идеалом «художественной цензуры» (В. Бранский), станет очевидным, что дальше декларации дело не продвигалось.

Казалось бы, в проповедуемом идеале сосредоточения требовали новые общественные роли женщины, но, судя по тому, какую высокую частотность обретало в этих произведениях определение «дахэ» (красивая), можно заключить, что в гораздо большей степени авторов занимала эстетика проявления этого идеала.

Стихотворения «Новая женщина» (1935) М. Афаунова и «Приветствие новым женщинам» (1935) А. Пшенокова роднит не только общая тема и связующий их образ, но и логика построения последнего. Оба автора словно пытаются свести воедино сущностную для них самих возвышенность, небесную недосягаемость женского образа и необходимую, диктуемую идеалом эпохи реалистичность, осязаемость ее вхождения в общественную жизнь. Условно в обоих произведениях можно выделить два мотива: культ запредельной женственности и «заземление» ее через предметность трудовых достижений. Упорное стремление привести к гармонии обе тенденции влечет за собой ощутимые перехлесты в употреблении эпитета «дахэ» и иных тропов, объединяемых значением «красота»: «Жизни цветущей листья, / Нрава красота чей закон»; «Красота кому одеянием (явилась), ваша (сейчас) весна. / Весенними листьями проросшие, / С самым красивым из благопожеланий к вам обращаюсь!»; «(Из) времен (самое) красивое - ваша жизнь» (А. Пшеноков «Приветствие новым женщинам») [7, с. 174].

В новой женщине все должно быть красиво - и нрав, и одеяние, и поступки, и труд, и мир, который ее окружает. Упомянув в тексте «Приветствия...» о метафоре Сулеймана Стальского ${ }^{4}$, А. Пшеноков создает собственный образ весеннего обновления - «жизни преображающейся листья» («гъащТэ щТэращТэм и пщащэ»), варьируя его как «распускающиеся весенние листья», «цветущие листья» («пщГащэу гъэгъахэ»). Складывается некий умозрительный пейзаж, на фоне которого новые женщины кажутся небесными вестницами, преображающими земную действительность. Мотив их прогрессивных трудовых свершений осмыслен по преимуществу в метафорическом ключе: «Знания лучом озаряя, / (Вы) партии ориентира держитесь. / В рядах сплоченно трудящихся пребывая / Красиво жизнь направляете» [7, с. 174].

М. Афаунов пытается синхронизировать в «Новой женщине» метафорический план воссоздания идеала («вы новая сила», «вы цветете подобно цветку лабазника», «вы умножаете мужество», «взлетев, вы кружите в облаках», «вы скопление солнц» и т. д.) и реалистический план ее трудовых свершений. Стоит заметить, что при этом на каждое прогрессивное действие героини приходится какое-то подспудное «но»: так, фиксируется не просто факт «седлания железного коня», но и воспитанность «наездницы», не просто значимость восхождения девушки на горную вершину, но и ее «безупречность»: «Наша Фаризат девушка воспитанная, / Нашего железного коня оседлала, / Девушка безупречная Дадуса / Эльбрус великий покорила» [7, с. 140].

Переходит ли плавно апология «женскости» в тему великих свершений либо развивается в метаниях от одного мотива к другому - так или иначе во все комбинации непременно вплетается этический момент - момент кротости и благонравия женщины. Что вполне объяснимо. Идеал новой женщины был ясен на уровне идейных предписаний эпохи, но вызывал растерянность и метания художественного сознания, пытающегося примирить новые реалии и значимую для сформировавшей его культуры ментальность. В свете имманентного адыгской культуре идеала корректировались роли и действия женщин, определялось их место в новой действительности. Они - «помощницы наших героев», - говорит М. Афаунов: «Наших героев-передовиков подспорьем / Большим отрядом вы трудитесь» [7, с. 141], а если и становятся руководителями, «то проходят плавно к почетному месту». Напрямую

\footnotetext{
4 Прибывший на Съезд женской молодежи Северного Кавказа (20 октября 1935 года) Сулейман Стальский обратился к его делегаткам со словами: «Желаю вам еще пышнее цвести - цветы нашего будущего!» (Сулейман Стальский. Сборник материалов и документов [Электронный ресурc]. Режим доступа: http//www.static.ow.ly/docs/Сулейман Стальский_1c9o.doc. По-видимому, это и имеет в виду А. Пшеноков, говоря в «Приветствии новым женщинам»: «УсакІуэ инуэ Стальскэм / И псалъэ ІэфІхэр фхуэфащэщ» - «Поэта великого Стальского / Слов приятных вы достойны».
} 
либо косвенно, но непременно оговаривается «вознесенность» новых женщин над привычным миропорядком: они - «лучом озаряющие» (Пшеноков), есть среди них «взлетевшие и средь облаков кружащие» (Афаунов).

Ни у Пшенокова, ни у Афаунова нет стремления к конкретизации чего-то нового в их облике, в обоих произведениях намечен обобщенный, почти абстрактный облик женственности в его устремленности к новой конкретике. И попутное обозначение Пшеноковым одежды новой женщины - всего лишь штрих этого обобщенного контекста: «Красота кому одеянием». У Афаунова в этом контексте обобщенно прекрасного облика вообще нет каких-либо «костюмных смыслов», зато есть упоминание красивого сложения, плавных движений ее тела: «Жизнерадостность в ваших ликах сияет, / Ваша мощь мужеству подобна, / (Вас) красиво сложенным телом плавно поводящих / В качестве руководителей на почетное место проводят» [7, с. 141].

Зачатки конкретизации облика и меняющейся психологии новой адыгской женщины проступают в произведениях Шогенцукова, созданных в том же 1935-м. Так, начальные строки стихотворения «Сатаней» дают понять, что новая суть, характер свободной независимой женщины сквозит уже в ее взгляде: «Черные большие глаза, на меня глядя, / Теперь ресницами не создают преграду, / Твои камышового оттенка пальцы, стесняясь, / В концы черного платка не станешь прятать. // Твой белый подбородочек, взмокая, / Черным шелковым платком не утянут, / А грудки твои маленькие теснящего / Kорсета ты уже тоже не носишь» [4, с. 117].

Сам по себе прямой взгляд женщины, обращенный к мужчине, в рамках кавказского менталитета - уже невероятный для своего времени прорыв. «Женщине не только не свойственно было находиться в обществе мужчины, но и при случайной встрече с ним она опускала свой взор и быстро проходила» [2]. Революционность этого прорыва подкрепляется и указанием определенных костюмных деталей, вернее, указанием отсутствия этих деталей - платка и корсета.

Платок ретроспективно «оформляет» беспокойный жест смущения, которое уже не вписывается в образ уверенной в себе героини. Так же как и корсет, он «стягивающий», «теснящий». Их отсутствие выступает одним из символов свободы, которая завоевывается, в том числе, и через отвержение прошлого. Можно сказать, что в творческом сознании Шогенцукова корсет («куэншыбэ») не просто неудобная деталь женской одежды, а символ социального угнетения. Во всяком случае, таковы его коннотации в стихотворении «Октябрь» (1939): «0ктябрь, радость несущий! / (C) Земного шара части шестой / Тумана корсет ты сумел сорвать, / В ветхих рубахах кого жить заставляли / По коже их огрубевшей рукой своею провел» [4, с. 168]. Стихотворение «Сатаней» также основано на соотнесении двух планов, - того, что отвергается из прежней жизни, и того, что пришло в настоящее. То, что ушло, показано через отрицание: ее «ресницы не создают преграду», «черным шелковым платком не утянута», «тес- нящего корсета не носит», «нет тех», кто обречет ее на домашнее заточение, «не появится тот», кто купит ее за калым. Все новое маркировано ее красотой: она «указывает белой рукой», «слаженно» трудится, она «красавица большеглазая», «моя красавица, моя душа», «цветущая», «все бытие преображающая». В завершение звучит призыв к ней стать борцом за справедливость, идеалом свободной женщины для женщин всего мира.

Корсет, как мы успели заметить, находится в ряду отвергаемых реалий старого мира. Ясно, что облик Сатаней меняется сообразно действительности, но смысл этого изменения не ограничивается сферой художественного символизма, а диктуется вполне реалистичными директивами эпохи, ведь отвергается, по сути, основа женской национальной одежды.

Корсет в традиционной адыгской культуре формирует образ идеальной красавицы, предполагающий тонкий стан и осиную талию. Ношение корсета представительницами адыгского этноса никогда не являлось данью переменчивой моде. Это была культурная традиция. С ранних лет корсет скульптурировал женское тело, предопределяя пластику его движений, приближая его к почитаемому исстари образу. Кроме того корсет выступал эстетическим маркером девичества. Как пишет Л. Сабанчиева, наряду с национальной шапочкой, куэншыбэ - «основной коррелят девушки» [8, с. 99].

В истории преображения Сатаней утверждение нового идеала непосредственно соприкасается с политической историей направленного вытеснения властью Советов женского национального костюма: «На областном съезде общественниц в Нальчике в 1927 году была объявлена борьба с ношением национальной одежды как “пережитком буржуазного общества", тот же вопрос прорабатывался и бытовыми комиссиями в 1929 году. Все это было равносильно борьбе с целым пластом материальной и духовной культуры и расценивалось местным населением как разрушение адыгских традиций и адыгской идентичности. В попытке вовлечь адыгскую женщину в процесс эмансипации и примеривая на нее равные с мужчиной политические свободы и социальные права, партийные органы примеряли на нее и новую форму одежды, видя в этой унификации составную часть решения проблемы равноправия или, иначе говоря, семантическое соответствие внешнего образа с содержанием процесса» [6, c. 319]. Как следует из приведенной цитаты, активная фаза процесса приходится на конец 1920-х годов. Шогенцуков пишет свое произведение в середине 30-х, но, видимо, в этот период осознание идеологической оппозиционности двух форм одежды все еще было заострено. В этом смысле щелковый платок («гуэлмэдын») и корсет («куэншыбэ») составляют мировоззренческую оппозицию красной косынке Лины-трактористки. Но, с другой стороны, в отличие от никак не обозначенной наружности Лины, красота Сатаней, если можно так сказать, осмыслена под традиционным для кабардинца углом зрения.

Здесь немаловажное значение имеет, конечно, и то, с какой отчетливостью вырисовываются личностные 
установки автора-мужчины, который не скрывает своего любования женщиной. Плотный шелковый платок и корсет в приведенном отрывке - это ведь еще и противовес подчеркнутой хрупкости женского облика: уменьшительно-ласкательные суффиксы, «оформляющие» части тела эмансипированной Сатаней («подбородочек», «грудки») говорят здесь сами за себя.

Безусловно, Сатаней обретает новые социальные роли, раскрывает новую суть, но, находясь пока еще на стыке прежних ценностей и новой социальной яви, тяготеет в большей мере к тому, чтобы остаться в пределах женственности в ее адыгской интерпретации, - это девушка с длинными волосами, красота которых передается через традиционный эпитет, в который, кстати, внедрен элемент национальной одежды - бурка: «Сатаней красавица большеглазая, / Золотисто-русые волосы чья бурка» [4, с. 118]. Так пролетарий, восторженно воспевающий новый строй, явственно уступает место мужчине, с большой нежностью и заинтересованностью любующемуся женской красотой. И вновь обилие характеризующих эту красоту слов. Вновь попытка примирения нового и привычного, пусть не реакционного, но стереотипного прочтения женского образа. Героиня Шогенцукова «преображающая», «красивая», «цветущая», «в солнечном луче растущая». Меняется лишь костюмный антураж, но этическое наполнение идеала, требования, к нему предъявляемые, остаются прежними - новая женщина несет в себе украшающее и преображающее жизнь начало. Таким образом, автор замыкает своеобразный круг, первоначально отвергая символы закрепощения, выраженные посредством костюмных атрибутов, намечая знаки новой личности и вновь возвращаясь к традиционному этническому идеалу.

Если сказанное относительно стихотворения «Сатаней» может показаться предположением, то другое - датированное тем же 1935-м — «Сатаней красивая» звучит его развернутым комментарием.

В название вносится, как мы теперь понимаем, сущностное для художественного сознания кабардинца, вживляющего в родную культуру новый идеал женщины уточнение - «красивая».

Приветствуя, как и прежде, новую женщину и ее новые роли, автор дает себе полную свободу погружения в стихию национальной образности, интерпретируя героиню и ее деяния в мифо-фольклорном ключе. Он создает образ, ассоциированный с величием кавказской природы, тем самым пытается подчеркнуть и его аутентичность, и его монументальность. Медленное пробуждение героини во вступлении открывает пейзажную панораму, в которой задействованы «древние горы», «далекие облака»: «Медленно, мягко вздыхает, / Белую руку подъемлет, / Протягивая ее к древним горам, (песню) слагает, / Свободно, красиво окидывает (окрестность) взором, / К дальним облакам / Тянется, чтобы их обнять».

Так же, как в предыдущем стихотворении, акцентирован жест прекрасных рук, на этот раз протянутых к горным вершинам, и взгляд, на этот раз «красиво окидывающий».
Реальность преображается сообразно ритму жестов этой женщины. Медлительные, плавные движения перемежаются указанием ее общественных свершений, и все вкупе напоминает магическое действо, по духу вполне отвечающее образу фольклорной Сатаней-гуаши ${ }^{5}$. гает песню, поднимая белую руку к старым вершинам»; «встает, солнцем Кабарды поднимается» и т. д. И здесь же - «правильные» с позиции идеологических ожиданий времени деяния: «С невежеством борется / К процветанию родины устремляется»; «Дремлющих (еще) сестер призывая, / Сея знание направилась»; «0на с миражами борется, / Мракобесов умерщвляет»; «Сатаней, красавица, поднялась / Защитницей женщин стала, / Красиво, тихо говорит, / Мудро, мягко упрекает» [4, с. 119]. При этом все проявления новой горянки корректируются в свете привычных для адыгской ментальности представлений об идеальном женском поведении: все совершает «мягко», «тихо», «красиво».

Лейтмотивом через текст проходят фразы «Сатанейкрасавица встала», «Сатаней-красавица поднялась», что равнозначно для Шогенцукова не только вознесенному положению героини, но и пробуждению ее мифологического величия. Это бессмертная героиня адыгских сказаний, которая пробудилась, чтобы призвать своих «дремлющих сестер».

Ее «прежние одежды» подобны непроницаемым покровам природы: «(Из) туманов, дымов в рубаху одетая, / Обманчивым сказаниям внимая <...> Разве осталась бы эта девушка необученной?» [4, с. 119]. А новое одеяние всего лишь намечено в традиционной для эпохи «лучащейся» палитре: она «окрашивается времени солнечным лучом», она «...сверкает, в знания одежды облачается».

Ее устремления полностью соответствуют идеологии нового времени и требованиям нового идеала, но при этом нет никакого соответствия каноническим моделям поведения пролеткультовской героини. Всякий раз изображается не движение, а царственный жест Сатаней. Не действие, а действо. В очертаниях ее наряда нет конкретики, но в его лучезарности прочитывается и метафора социалистической нови, и характеристика запредельной красоты героини. Перед нами древний образ, преломляемый в свете новых идеологических ожиданий, однако нравственноэстетическое его наполнение определяют не каноны новой идеологии, а традиции адыгского фольклора.

Добавим, что активистка Шогенцукова и в других случаях лишена резкости и порывистости, она «мягко участвует в партийном сходе», «красиво, тихо говорит» [9, с. 134, 148]. Она чрезмерно нежна и женственна для нравственно-эстетических нормативов пролетарской поэзии. Такой идеал дисгармоничен в отношении пролеткультовской логики, но последователен в смысле полного соответствия интерпретации женственности конкретным этносом. И упорное стремление художника постоянно

\footnotetext{
${ }^{5}$ Сатаней, Сатаней-гуаша - героиня адыгского нартского эпоса, наставница нартов, мать Сосруко, женщина неувядающей красоты и молодости.
} 
удерживать в поле зрения эту женственность, как нам кажется, значимо для него не менее чем стремление лицезреть, как реализуется свобода горянки. Поэтому параллельно искреннему стремлению соответствовать нормативам эпохи, осознанно или нет, врывается и собственный идеал. За всем этим читается устойчивость привычных стереотипов, в согласии с которыми «мужчины и женщины, каждый занимая свою социальную нишу, по закону диалектики взаимодополняли друг друга» [8, с. 109].

Заглядывая вперед, можно сказать, что по прошествии короткого времени красота новой женщины в кабардинской поэзии утрачивает величественный мифо-фольклорный ореол. Уже в начале 1940-х героини кабардинской поэзии перестают порхать в небе, царственно взмахивать рукой, отныне вполне реалистично рассекая на грузовике труднодоступные горные тропы, проводя научные наблюдения на вершине Эльбруса. Их костюмный облик обретает новые детали, например, в виде дырочки для ордена на красивом платье. В подтверждение достаточно назвать хотя бы произведения Алима Кешокова «Девушка-шофер» (1945) и «В тот вечер осенью туманной» (1947).

Несколько обособленно от поэтических опытов раннесоветского периода выступает феномен, который в 1930-е годы сыграл заметную роль в утверждении культуры нового типа - творчество Индриса Мухамедовича Кажарова (1895-1941). Его произведения определяют этап становления книжной поэзии, на котором привычная адыгам стихия народного песнетворчества вступила во взаимодействие с новым типом сознания и начала осваивать язык новой культуры.

Как в дооктябрьский период, так и в последующие годы особое место в произведениях Кажарова занимала «женская тема», так же как тема костюма занимала особое место в его жизни.

Помимо таланта музыканта и сочинителя, Кажаров владел тонкостями портновского искусства. По воспоминаниям тех, кто был лично знаком с мастером, можно понять, что совершенство созданных им изделий принимало почти магический оттенок: «Если неженатый парень надевал сшитую Индрисом одежду, за него соглашалась пойти приглянувшаяся ему девушка, если же девушка в платье его работы появлялась на улице, либо на джегу ${ }^{6}$, за этим следовало скорое сватовство ее и замужество» [10, с. 62]. В свое время Кажаров «был единственным в республике кабардинцем-гармонистом высокого класса, песенником-самородком, мастером по пошиву верхней одежды» [11, с. 4]. Закономерно, что именно ему было поручено создание костюмов для участников хора, организованного при радиокомитете Кабардино-Балкарии в начале 1930-х. Закономерно, что именно с его легкой руки и хор, и, разумеется, ансамбль песни и пляски сохранили стилистику национального костюма.

Безусловно, в творческом сознании подобного человека детали одежды не могли быть незначимыми. Они

\footnotetext{
${ }^{6}$ Джэгу - адыгское игрище.
}

присутствуют почти во всех его произведениях. Будучи в ряду создателей советской кабардинской песни, устремленной к новой идеологии, он избирает символом перемен внутренний мир своих героинь. Как отмечает 3. Налоев, «Индрис выступает защитником прав женщин на свободный выбор любимого, против деспотической власти родителей и родственников. Это было продолжением и развитием гыбзового7 мотива, многие века разрабатываемого не только самими женщинами, которые пели о своей трагедии, но также от их лица - профессиональными джегуако ${ }^{8}$ и орадусами ${ }^{9} . . »[13$, с. 380$]$.

В каждом произведении этого ряда намечен протест, и протест этот исходит от первого лица, то есть наблюдается его нарастание «изнутри», от эстетизированного песенной традицией женского самооплакивания - к дерзким угрозам и твердой вере в торжество свободного выбора, собственного определения судьбы. Выразительница этого протеста, транслятор новых ценностей - все та же прекрасная девушка с тонким станом. Так, в одной из ранних песен облик героини обрисован формульными определениями: «Луна чей лик / В ладонь шириной чья талия» [12, с. 20].

Можно понять, что устремленность к новому идеалу не могла привести к мгновенному отрицанию привычной каноничности облика. Однако примечательно, что Кажаров, находившийся в гуще культурной жизни республики, испытывавший определенное влияние новой культуры и создавший на этой волне цикл песен о новых людях, об успехах социалистического строительства [13, с. 386], в изображении центрального образа своей поэзии все же оставался верен консервативным тенденциям.

Упоминание «костюмного облика» чаще всего сопряжено в его текстах с весьма распространенной традицией народных песен, по этой причине смысл деталей, подчиненных задаче развертывания звуковой темы, может показаться нейтральным. Так, в популярной по сегодняшний день песне Кажарова «Рамазан», появившейся как вольное переложение адыгейского произведения, начальные строки, вроде бы мало связанные с сюжетом, намечают изысканность костюмного облика героини: «Мои туфельки красивые, еууей жи ${ }^{10} / \mathrm{У}$ носков моих щебечут, рэуэу жи $\left.{ }^{11} \gg\right)[12$, с. 16].

Как оценивает текст «Рамазана» 3. Налоев, в авторской интерпретации народной песни «феминистический дух оригинала зазвучал более современно, в плане борьбы за эмансипацию женщин» [13, с. 35]. Интересно, что дух этот в сознании художника не диссонирует внешней утонченности его носительницы. По мере развертывания произведения мы замечаем на героине аксессуары, углубляющие

\footnotetext{
7 Гыбза (каб.-черк. «гъыбзэ») - жанр старинных народных песен адыгов, песня-плач.

${ }^{8}$ Джегуако (каб.-черк. «джэгуакІэ») - общее обозначение артистов и певцов-импровизаторов в традиционной культуре адыгов.

${ }^{9}$ Орадус (каб.-черк. «уэрэдус») - сочинитель песен.

${ }^{10}$ Еууей жи - ритмообразующий элемент с эмоциональным оттенком досады.

11 Рэуэу жи - ритмообразующий элемент.
} 
акцент женственности - «шелковый шарф» и «красивое кольцо», - атрибуты весьма отдаленные от ценностей новой культуры: «Мой шелковый шарф, еууей жи, / Под подбородком тоскует, рэуэу жи»; «Мое кольцо красивое, еууей жи, / Палец отекающий сжимает» [12, с. 17].

В песне «Любимый и есть красивый» мимоходом упоминается утонченный аксессуар адыгского женского костюма «дэнльэч» - плетение из золотой канители, использовавшееся для украшения адыгской национальной одежды, в особенности шапочки, и отмечается пышность наряда героини: «Моя младшая сестра / Золотое плетение скрепляет, уей ${ }^{12}$, / От людей в тайне / Я ведь тебя сердцем приняла, / Тот, кто нравится, и есть красивый, уей. / Мое платьице с юбкой пышною, уей, - / Я пропадаю из-за своей смелости, / Тот, кто нравится, и есть красивый, уей» $[12$, с. 11$]$.

Если вывести закономерность, кроющуюся за привычным, казалось бы, приемом, обнаружится, что угнетенная, с пробуждающимся осознанием борьбы за лучшую долю героиня Кажарова всегда предстает в нарядном одеянии, всегда щедро украшена.

Заметным отступлением от общей тенденции может быть штрих к костюмному портрету молодой колхозницы Таужан: «Утро веет свежестью, / С открытой шеей Таужан выходит» («Таужан»). В этом коротком штрихе - и дерзновенность натуры героини, и определенное отступление от этикетных норм ношения адыгами одежды [14, с. 54]. Причем здесь мы имеем редкий в преломлении Кажаровым «женской темы» случай предпочтения «внешней» точки зрения «внутренней», что в данном случае усиливает декларативность образа Таужан.

Но в это же время появляется песня «Жестокость», где сетующая на свою горькую долю героиня уже во вступлении предстает в парчовом одеянии: «Мои парчовые наряды вкруг меня колышутся, / Я, кружа, / Совсем одна / Подворье обхожу» («Жестокость») [12, с. 25]. Опять же угнетаемая, притесняемая женщина, протестующая против законов прежнего уклада, красиво и даже богато одета. Повторим, что включение деталей костюма лишь поддерживает звуковую тему: «Си шылэхъарыр зэрыкIапищ, / Си анэ къилъхуаищым / Сакъыкъуэмынэу / Емынэунэхэ сынашэжащ». - «Мой шелковый платок с тремя концами, / С рожденными моей матерью тремя / (С ними) меня не оставляя, / В ненавистный дом меня вернули» [12, c. 25]. Но одно остается бесспорным - для данной цели избираются не просто этнические, но еще и изысканные детали костюма.

Несколько странной для автора, провозгласившего идеал равноправия в образе передовой бригады, состоящей из одних лишь женщин («(И) без участия мужчин из одних женщин состоящую / Бригаду на коней посадим» («Песня доблестных стахановцев») [12, с. 23], кажется социальная атрибуция наряда, вызывающая вопрос: а правомерно ли появление в контексте пролетарской

\footnotetext{
12 Уей — ритмообразующий элемент.
}

культуры героини в парчовом одеянии? Если допустить приверженность Кажарова прежней шкале ценностей, правомерно, ведь кабардинцы, независимо от социальной принадлежности, стремились одевать своих дочерей с изыском.

Устремленность Кажарова к идеалу нового человека, судя по всему, при этом никак не ущемлялась и не вступала в конфликт с системой ценностей, имманентных родной культуре. Каноническая эстетика женского образа, утвердившаяся задолго до революционных преобразований кабардинского общества, в его сознании никак не противоречит образу «новой женщины». Резонно предположить, что так происходит по одной причине. Протестующие и вливающиеся своим протестом в патетику революционного времени героини Кажарова всегда отстаивают одну и ту же ценность - право на любовь. Данный мотив его поэзия впитала задолго до Октября, в дальнейшем же ценность мотива и ценности переустройства жизни находят точки соприкосновения, идеал Кажарова оказывается созвучным великому преобразующему перелому.

Последнее из того, что было создано И. Кажаровым - стихотворение «Любовь», выступает итоговым доказательством наших предположений. Выстроенное в форме монолога молодой жены красноармейца, оно так же не лишено интересующих нас деталей. Реалии, обусловившие драматизм сюжета, новые, но они и порождают новые причины для того, чтобы реализовать привычную для традиционной поэзии адыгов форму выражения «женской темы» — песню-плач и воссоздать отвечающий ей образ женщины.

В сетования героини вплетаются детали создаваемого ею свадебного одеяния из белого шелка: «Моя белая ткань шелковая в два сложения, / Край ее красиво подшиваю, / Многих парней отвергая, одному лишь согласие дала, / Красная армия призвала, он служить пошел» [12, с. 28].

Судя по всему, молодая жена красноармейца после умыкания была доставлена не в дом родителей жениха, а к дальним родственникам или к друзьям. Отсюда и просьба молодой: «Если помнишь власть, не оставляя (здесь) / К вашим меня отвези» $[12$, с. 28]. Красноречива апелляция героини к новой власти как к безусловной ценности, но весь трагизм ее положения «завязан» именно на невозможности преступить освященные адыгским этикетом законы. Она накидывает на свою шею шелковый платок, - действие, предписываемое костюмным этикетом адыгов, поскольку платком новобрачная по обычаю заменяла девичий головной убор - шапочку, правда, совершалось это после рождения первенца, но в данном случае героиня хочет сказать о двусмысленной преждевременности своего нового статуса: «Мой шелковый платок квадратный, / В тот день на шею свою набрасываю, / За один месяц в положении разведенной очутившуюся / Меня ты покинул / На люди не показываюсь» [12, с. 28]. Реалии, как было сказано, новые, но костюмный этикет, составляющий абсолютную параллель этикету поведения, прежний. 
Таким образом, смыслы, сосредоточенные в привычных для песенного фольклора деталях, свидетельствуют о неосознанной попытке сохранения, вопреки всем преобразованиям реальности, той интерпретации женского образа, которая согласуется с нормативами аутентичного для адыгской культуры идеала.

Трудно сказать, какие изменения претерпел бы образ женщины, если бы жизнь и творчество И. Кажарова имели продолжение, но анализ деталей даже в том малом объеме произведений, по которому мы судим, позволяет ощутить доминирование прежнего идеала, выраженное явно и неоднократно.

Первое, что бросается в глаза при беглом взгляде на функции, которые в текстах раннесоветского периода выполняют детали мужской одежды, это то, что никаких перемен, ответствующих духу нового времени, с ней не происходит. Появление в тексте деталей мужского национального костюма всегда несет положительный смысл это прежде всего символ доблести.

Стихотворение Шогенцукова «Данох» (1940), стилизованное под женскую песню-плач, завершается следующими словами: «С кольчужными рукавами ведущего всадника / (Его) любовь позабыть меня не заставят / Старика-князя полуседого с кожей окоченевшей / От того, что к себе привлечешь, тебя не согреет» [4, с. 181]. Насильно выданная за немощного старика Данох, через оппозиционную в контексте ее сетований пару «кольчуга / окоченевшая кожа», конечно, подразумевает не простое противопоставление молодости и старости, но его моральную подоплеку - доблесть / немощь. Это усилено и аллюзивным сближением с известной строкой историко-героической «Песни об Андемиркане ${ }^{13}$ »: «Его кольчужный рукав ему щитом (является)» (цит. по: [13, c. 319]).

Разумеется, наряду с привычными деталями в кабардинскую поэзию привходит и нечто новое, так, шинель и национальная мужская одежда оказываются в одном семантическом поле. В стихотворении «Баю-бай, мой мальчик» (1936) обнаруживаем такой фрагмент: «Старшие братья тебе книги / Золотыми буквами печатают, / Для тебя Красная Армия на шинелях / Ордена большие прикрепляет» [4, с. 143]. Шинель параллельно с кольчугой есть символ доблести, с той лишь разницей, что детали мужского национального костюма на всех этапах развития кабардинской поэзии имеют этическое измерение. Кольчуга, черкеска, шлем - это всегда смысловая отсылка к этическому кодексу адыгов (адыгэ хабзэ), сложившемуся еще в Средневековье, но в поэтических текстах они принимают функцию не столько символа отдаленной эпохи, сколько нравственного императива.

Так, для ранней поэзии А. Кешокова, как и для его учителя А. Шогенцукова, характерно радостное приня-

\footnotetext{
${ }^{13}$ Андемиркан - легендарный герой Кабарды периода Средневековья, бесстрашный рыцарь, защитник угнетенных, один из наиболее почитаемых мужских образов фольклорных сказаний и песен адыгов.
}

тие нового строя, и в этом новом мире элементы мужской национальной одежды продолжают транслировать возвышенные смыслы. Они выступают символами доблести и нравственной высоты. С тем только отличием Кешокова от предшественников и современников, что эти «означающие» доблести и нравственной высоты (кольчуга, черкеска, шапка, бурка) в абсолютном большинстве случаев сосредоточены вокруг самого лирического героя.

Таким образом, прочтение поэтических текстов с точки зрения «костюмных смыслов» с целью доказательства, что в период радикальных преобразований выбор идеала осуществлялся в том числе и через выбор костюмного облика, в итоге открывает неоднозначность этого выбора и параллельно то, что лишь в контексте женского одеяния оказалось возможным сопоставление / противопоставление современности и прошлого. Новая реальность диктовала новую мораль, иные модели поведения, намеченные в рассмотренных образцах через прямой взгляд Сатаней, свободной от «теснящего грудь корсета», через красную косынку Лины, оседлавшей «железного коня», но этический идеал художника, просвечивающийся сквозь некоторые эстетические трансформации, желал оставаться прежним.

\section{Список литературы}

1. Манкевич И.А. Поэтика обыкновенного: опыт культурологической интерпретации. - СПб., 2011.

2. Сагирова М. Горянка в Советском Союзе [Электронный ресурс]. - Режим доступа: http://www.islamdag.ru/ istoriya/13390

3. Текуева М.А. Повседневная жизнь женщины в адыгском традиционном обществе [Электронный ресурс]. - Режим доступа: http://www.kbsu.ru/Info/sgi/sgi_Tekueva1.doc

4. Шогенцуков А.А. Сочинения (на кабардинском языке). Нальчик, 2006.

5. Шогенцуков А.А. Собрание сочинений (на кабардинском языке). Том I. - Нальчик, 1961.

6. Текуева М.А. «Решение» женского вопроса в КабардиноБалкарии в 1917-1941 гг. [Электронный ресурс]. - Peжим доступа: http:// www.kbsu.ru/Info/sgi/sgi_Tekueva2. doc

7. Сделавшие первый шаг (на кабардинском языке). - Нальчик, 1968.

8. Сабанчиева Л.Х. Гендерный фактор в традиционной культуре кабардинцев (вторая половина XVI - 60-е годы XIX века). - Нальчик, 2005.

9. Кажарова И.А. Образы «новой действительности» в поэзии Али Шогенцукова // Вопросы кавказской филологии. Вып. 8. - Нальчик, 2011.

10. Таким остался в сердцах людей // Ошхамахо (на кабардинском языке). - 1993. - № 6.

11. Кумыков Х. Месть сестры жены военкома // Газета Юга. 2014, 12 июня.

12. Кажаров И.М. Песни (на кабардинском языке). - Нальчик, 1959.

13. Налоев 3.М. Институт джегуако. - Нальчик, 2011.

14. Кажарова И.А. Оппозиция «душа/тело» в адыгской поэзии // Человек - 2013. —№ 1. 